\title{
A note on the composition and nutritional value of hulless barley
}

\section{Danuta Boros, Barbara Rek-Ciepły and Małgorzata Cyran}

\author{
Department of Biological Evaluation of Plant Products, \\ Institute of Plant Breeding and Acclimatization \\ Radzików, 05-870 Blonie, Poland
}

(Received 8 July 1996; accepted 13 September 1996)

\begin{abstract}
Chemical and biological methods were used to determine the nutritional value of three recently developed strains of hulless barley compared with a commercially grown hull-containing cultivar in Poland. The following quality criteria were used: protein content and composition, dietary fibrc (DF) and non-cellulose polysaccharides (NCP), protein (TD) and dry matter digcstibility (DMD) as well as biological value (BV) and protein utilization (NPU) in rats. All tested hulless barleys had higher protein contents ( 15.3 vs $13.4 \%$ ) but lower lysine concentrations in their protein (2.86 vs. 3.14$)$ than the hull-containing one. The lack of hulls in barley resulted in lower insoluble dietary fibre (IDF) and insoluble arabinoxylan contents (by 44 and $41 \%$, respectively) and in a higher soluble $\beta$-glucan (by $58 \%)$ content. In rats, TD and DMD were positively corrclated with protein content $(r=0.80$ and $0.78)$ and negatively with IDF content $(r=-0.75$ and -0.95$)$. It seems, therefore, that the nutritive value of hulless barleys was distinctly better than that of the hull-containing cultivar.
\end{abstract}

KEY WORDS: dietary fibre, polysaccharides, $\beta$-glucan, protein utilization, digestibility, rats, hulless barley

\section{INTRODUCTION}

The high amount of insoluble fractions of nonstarch polysaccharides (NSP) in hull-containing barley is a major impediment to its use in diets, especially for young pigs. The hull comprises $10-13 \%$ of barley dry matter (Bhatty, 1986), therefore its absence in hulless forms results in the greater content of nutrients, mainly protein and fat. The presence of hull, which is made up of chiefly cellulose 
and lignin, decreases the digestibility of all nutrients, mostly protein and energy in monogastrics. These fibre fractions increase the motility of the animal digestive tract, shorten the time of digesta passage and enzyme activity. Consequently, the hull has an undesirable effect on utilization of nutrients from a barley diet. Hulless barley, with its decreased content of these compounds, has a great future in feeding monogastric animals as soon as the problem of low yield and disease resistance will be overcome in Polish breeding. Hulless feature of barley has been known for a considerable time. However, it was only in the early eighties when forms suitable for cultivation as a feed grain were developed. They give good yields and are disease resistant (Bhatty, 1986).

The study was undertaken to evaluate by chemical and biological methods, the nutritional value of recently developed hulless barley as compared with a commercially grown hull-containing cultivar in Poland.

\section{MATERIAL AND METHODS}

Three strains of hulless (RAH-735/93, RAH-736/93 and RAH-738/93) and one hull-containing barley (cv. Lot) used in this study represented spring, two-rowed barley and were grown at the Breeding Station in Radzików in 1994. The tested strains of barley gave yields equivalent to 85 to $92 \%$ of that of the reference cultivar (Lot); all the grains were completely devoid of hulls (Polkowski, 1996). Prior to analysis or inclusion into diets the samples were ground to pass a $0.5 \mathrm{~mm}$ screen.

Crude protein $(\mathrm{N} \times 6.25)$ was determined by the K.jeldahl method using a Tecator semiautoanalyzer, and dry matter by a standard method (AOAC, 1990). Amino acids were analysed on a Beckman $119 \mathrm{CL}$ autoanalyzer, after acid hydrolysis in $6 \mathrm{~N} \mathrm{HCl}$ as described by Mason et al. (1980). The content of dietary fibre (DF) was determined by the gravimetric method of Asp et al. (1983), while that of $\beta$-glucans according to the method of Åman and Graham (1987). The insoluble (IDF) and soluble (SDF) fractions of DF were hydrolysed with $2 \mathrm{~N}$ trifluoroacetic acid (TFA) at $125^{\circ} \mathrm{C}$ for $1 \mathrm{~h}$, then were analyzed for non-cellulose polysaccharides (NCP) and their constituent sugars as aldononitrile acetates by gas liquid chromatography using the method of McGinnis (1982). All analysis were performed either in duplicate or triplicate and expressed on dry matter basis.

The balance experiments were carricd out on Wistar rats as described by Eggum (1973). True digestibility (TD), biological value (BV), net protein utilization (NPU), and dry matter digestibility (DMD) were used as criteria of nutritional quality and were measured on the basis of total urine and faeces collections during 5 days of a balance period. 
The data were subjected to one way analysis of variance and Tuckey's multiple range test. The minimum level of statistical significance was $\mathrm{P}<0.05$.

\section{RESULTS AND DISCUSSION}

\section{Dietary fibre and protein composition}

The composition of barley protein and fibre is given in Tables 1 and 2 . The protein content in hulless barleys ranged from 14.62 to $16.65 \%$ and was on average 1.93 percentage points higher than in the hull-containing cultivar. These results are consistent with those reported by Bhatty (1986) who also found a higher protein content in hulless barley. The concentration of the first limiting amino acid, lysine, was lower in the crude protein of hulless barleys, except for

TABLE 1

Amino acid composition of barley, g/16 g N

\begin{tabular}{lrrrr}
\hline & \multicolumn{4}{c}{ Type of barley } \\
\cline { 2 - 5 } Amino acids & hulled & \multicolumn{3}{c}{ hulless } \\
\cline { 2 - 5 } & \multicolumn{1}{c}{ Lot } & RAII-735/93 & RAH-736/93 & RAH-738/93 \\
\cline { 2 - 5 } CP, \% DM & 13.41 & 14.75 & 16.65 & 14.62 \\
Lys & 3.14 & 2.73 & 2.61 & 3.25 \\
Met & 1.64 & 1.80 & 1.43 & 1.74 \\
Cys & 1.62 & 1.66 & 1.73 & 1.67 \\
Thr & 3.24 & 3.49 & 3.83 & 3.06 \\
lle & 5.25 & 3.72 & 3.74 & 4.12 \\
Arg & 4.96 & 4.97 & 4.59 & 5.82 \\
His & 2.14 & 2.08 & 2.18 & 2.52 \\
Leu & 7.05 & 6.79 & 7.15 & 6.89 \\
Phe & 4.12 & 5.29 & 5.21 & 4.58 \\
Val & 6.44 & 5.00 & 4.60 & 5.98 \\
Ald & 3.41 & 3.35 & 3.78 & 3.70 \\
Asp & 6.42 & 6.17 & 5.86 & 6.24 \\
Glu & 21.73 & 24.70 & 25.47 & 24.64 \\
Gly & 3.46 & 3.42 & 3.74 & 3.69 \\
Pro & 9.80 & 12.52 & 15.37 & 12.67 \\
Ser & 4.27 & 4.81 & 4.46 & 4.63 \\
Tyr & 2.22 & 3.12 & 3.29 & 2.79 \\
Total AA & 90.91 & 95.62 & 99.04 & 97.99 \\
Total EAA & 41.82 & 40.65 & 40.36 & 42.42 \\
\hline AA, & & & & \\
\hline
\end{tabular}

' AA, amino acids; ${ }^{2}$ EAA, essential amino acids 
TABLE 2

Dietary fibre content and non cellulose polysaccharides (NCP) compositon of barley, \% DM (values in parentheses are soluble-NCP)

\begin{tabular}{lcccc}
\hline Items & Lot & RAH-735/93 & RAH-736/93 & RAH-738/93 \\
\hline Dietary fibre & & & & \\
$\quad$ soluble & 6.67 & 6.20 & 6.97 & 6.43 \\
$\quad$ insoluble & 15.70 & 8.78 & 8.69 & 8.91 \\
$\quad$ total & 22.37 & 14.98 & 15.66 & 15.34 \\
NCP & & & & \\
$\quad \beta$-glucans & $3.62(1.95)$ & $5.33(2.85)$ & $5.04(2.96)$ & $5.29(3.44)$ \\
$\quad$ arabinoxylans & $7.80(0.62)$ & $4.80(0.55)$ & $4.79(0.67)$ & $4.90(0.56)$ \\
$\quad$ total & $13.5(4.67)$ & $10.8(4.86)$ & $11.9(6.32)$ & $11.1(5.23)$ \\
\hline
\end{tabular}

one form, and was on average 0.28 percentage points lower than in the hull-containing barley. However, the content of limiting amino acids in grain dry matter in two forms of barley was almost identical. Similar results were obtained by Bhatty et al. (1979).

There were no marked differences in SDF content (Table 2) of hull-containing and hulless barłey (6.67 vs. $6.53 \% \mathrm{DM})$. The latter forms had significantly lower IDF and consequently TDF contents, about 6.5 percentage points lower than in the Lot cultivar. The total content of $\mathrm{NCP}$ was the highest in hull-containing barley and noticeably lower in hulless forms ( $13.4 \mathrm{vs.} 11.3 \%$ ). The higher content of total NCP in hull-containing barley was accompanied by higher insoluble arabinoxylan content ( 7.18 vs. $4.24 \%$ ). A similar amount of pentosans in hull-containing two-rowed barley, varying from 7.3 to $10.6 \%$, was found by Bach Knudsen et al. (1987a) in Danish cultivars. Similarly, lower contents of pentosans in hulless barley were also found by Bengtsson et al. (1990) and Bhatty et al. (1991). These results show that the pentosan content is affected by the presence of hull, cultivar, and environment (Åman and Graham, 1987; Bhatty et al., 1991). In contrast, hulless barleys contain 44 and $58 \%$ more total and soluble $\beta$-glucans, respectively, than the hull-containing Lot cultivar, which is consistent with the results of other studies (Bhatty, 1987; Bhatty et al. 1991). In the present study, soluble $\beta$-glucans formed, on average, $57.8 \%$ of the total $\beta$-glucan content, exceeding the values of 44.7 and $32.7 \%$ reported earlier by Bhatty et al. (1991) and Bhatty (1987), respectively, but in agreement with those obtained by Åman and Graham (1987). Smith et al. (1980) found that up to $67 \%$ of total $\beta$-glucans were soluble in poor malting barley and only $25 \%$ in good malting barley. The wide variation that exists both in content and in solubility of $\beta$-glucans is influenced by genotype and environment ( $\AA$ man and Graham, 1987; Bach Knudsen et al., 1987a). 


\section{Biological evaluation}

The results of biological evaluation are shown in Table 3 . True protein digestibility was significantly $(P<0.05)$ higher for hulless barley than for hull-containing ones and was related to protein $(r=0.80)$ and IDF $(r=-0.75)$ content (Table 4). It is well known that the increase in protcin content in most cereals is associated with raised storage protein concentrations, and that these proteins are highly digestible but low in lysine content (Eggum and Beams, 1983). Also in barley, TD increases and BV decreases with increasing amount of protein (Horaczyński et al., 1981). In this study, protein quality measured by BV was also negatively correlated with protein content $(\mathrm{r}=-0.81)$ and positively with lysine concentration $(r=0.75)$ and therefore in hulless barleys, which contain more protein, was significantly $(\mathrm{P}<0.05)$ lower than in the hull-containing form (Table 4). According to Sauer and Ozimek (1986) the high inclusion of fibre into diets affects protein digestibility. These authors claim that fibre, depending on

TABLE 3

True protcin digestibility (TD), biological value (BV), net protein utilization (NPU) and dry matter digestibility (DMD) of barley in rats

\begin{tabular}{lcccc}
\hline Dict & TD & BV & NPU & DMD \\
\hline Lot & $79.2^{\mathrm{c}}$ & $73.8^{\mathrm{a}}$ & $58.4^{\mathrm{a}}$ & $84.9^{\mathrm{c}}$ \\
RAH-735/93 & $81.3^{\mathrm{b}}$ & $68.8^{\mathrm{a}}$ & $55.7^{\mathrm{b}}$ & $90.5^{\mathrm{b}}$ \\
RAH-736/93 & $84.9^{\mathrm{a}}$ & $67.7^{\mathrm{c}}$ & $57.4^{\mathrm{ab}}$ & $92.0^{\mathrm{a}}$ \\
RAH-738/93 & $83.7^{\mathrm{a}}$ & $71.0^{\mathrm{b}}$ & $59.5^{\mathrm{a}}$ & $91.4^{\mathrm{ab}}$ \\
Pooled SEM & 0.46 & 0.58 & 0.51 & 0.38 \\
\hline
\end{tabular}

$a, b, c$ - values within a column sharing the same superscript are not significantly different at $P<0.05$; SFM, standard error of the mean

TABLE 4 Correlation coefficients between protein, lysine, total (TDF), insoluble (IDF) and soluble (SDF) dietary fibre, and total $\beta$-glucan contents vs. TD, BV and DMD

\begin{tabular}{llll}
\hline Diet & TD & BV & DMD \\
\hline Protein & $+0.80^{* *}$ & $-0.81^{* *}$ & $+0.78^{* *}$ \\
Lysine & -0.32 & $+0.75^{* *}$ & -0.43 \\
TDF & $-0.70^{* *}$ & $+0.75^{* *}$ & $-0.92^{* *}$ \\
IDF & $-0.75^{* *}$ & $+0.78^{* *}$ & $-0.95^{* *}$ \\
SDF & +0.33 & -0.02 & -0.09 \\
$\beta$-glucan & $+0.67^{* *}$ & $-0.71^{* *}$ & $+0.91^{* *}$ \\
\hline
\end{tabular}

** correlation significant at $\mathrm{P}<0.01, \mathrm{n}=20$ 
the degree of lignification, may adsorb amino acids and peptides and impair their absorption. Furthermore, fibre may decrease the activities of trypsin and chymotrypsin (Schneeman et al., 1982) and also physically impede the access of proteolytic enzymes. In contrast, Bach Knudsen et al. (1987b) reported that although TD in rats was affected by year and type of barley cultivar, these variations were not correlated with any of the DF constituents. Actually, the variability in DF content of nine barley samples used in their study was much lower than in the present one. It is noteworthy that in the current study, one strain of hulless barley with a higher lysine content and significantly higher $(\mathrm{P}<0.05)$ BV value than the other hulless forms also had a high TD. Consequently, the NPU for this strain was the highest among the tested hulless barleys.

The lack of hull significantly affected $(P<0.05)$ the DMD, which was 6.4 digestibility units higher in hulless samples as compared with the Lot cultivar. The correlation between IDF and DMD was high $(r=-0.95)$. Bach Knudsen et al. (1982), who studied the nutritional value of mill fractions of barley, found that high addition of hull, rich in IDF fractions, drastically reduced both digestibility of protein and energy of that diet in rats as compared with those fed on an endosperm-containing diet. This was especially true for low energy digestibility, since almost all the DM in the hull diet was recovered in faeces. The main reason of such a marked negative impact of IDF fractions was assumed to be reducing transit time, thus leaving less time for microbial fermentation.

In the present study, it was shown that increased soluble $\beta$-glucan content did not affect the digestibility of any tested dict component. A study in pigs showed that faecal $\beta$-glucan digestibility equaled $100 \%$, suggesting substantial degradation of this sugar by endogenous feed enzymes and bacteria in the anterior part of the gastrointestinal tract (Graham et al., 1986). Furthermore, enzyme supplementation did not significantly improve the nutritive value of barleybased diets for pigs in their study.

\section{CONCLUSIONS}

The present data confirm the view that the genotype of barley influences $\beta$-glucan content to a high degree, and of protein to a lesser extent. In general, the hulless forms contain more protein and soluble $\beta$-glucans than hull-containing ones. However, this higher content of soluble $\beta$-glucans does not affect the digestibility of protein and dry matter. The major factors affecting the digestibility of nutrients from a barley based-diet are the insoluble fractions of dietary fibre. Thus, hulless barley with its substantially decreased content of these fractions has a superior nutritional, especially energetic, value than the 
hull-containing cultivars. However, for better utilization of protein, in practice, hulless barley dicts should be supplemented with more lysine than diets with hullcontaining barley.

\section{ACKNOWLEDGMENTS}

The authors thank W. Polkowski from the Breeding Station in Radzików for providing the grains and E. Durawa and A. Jankowska for their excellent technical assistance. We also would like to thank Grindsted Prod., Denmark for donating the $\beta$-glucanase.

\section{REFERENCES}

Åman P., Graham H., 1987. Analysis of total and insoluble mixed-linked (1@3),(1@4)- $\beta$-D-glucans in barley and oats. J. Agric. Food Chem. 35, 704-709

AOAC., 1990. Association of Official Analytical Chemists, Official Methods of Analysis .15th Edition, Washington, DC

Asp N.G., Johansson C.G., Hallmer H., Siljeström M., 1983. Rapid enzymatic assay of insoluble and soluble dietary fiber. J. Agric. Food Chem. 31, 476-482

Bach Knudsen, K.E., Wolstrup J., Eggum B.O., 1982. The nutritive value of botanically defined mill fractions of barley. 2. The influence of hind-gut microflora in rats on digestibility of protein and energy of endosperm and husk of Bomi and M-1508. Z. Tierphysiol. Tierernähr. Futtermittelk. $48,276-287$

Bach Knudsen, K.E., Åman P., Fggum B.O., 1987a. Nutritive value of Danish-grown barley varieties, I. Carbohydrates and other major constituents. J. Cereal Sci. 6, 173-186

Bach Knudsen K.E., Eggum B.O., Jacobsen I., 1987b. Nutritive value of Danish-grown barley varieties, II. Effect of carbohydrate composition on digestibility of energy and protein. J. Cereal Sci. 6, 187-195

Bengtsson S., Åman P., Graham H., Newman C.W., Newman R.K., 1990. Chemical studies on mixed-linked $\beta$-glucans in hull-less barlcy cultivars giving different hypocholesterolaemic responses in chickens. J. Sci. Food Agric. 52, 435-445

Bhatty R.S., Christison G.I., Rossnagel B.G., 1979. Energy and protein digestibilities of hulled and hulless barley determined by swine-feeding. Can. J. Anim. Sci. 59, 585-592

Bhatty R.S., 1986. The potential of hull-less bartey - a revicw. Cereal Chem. 63, 97-103

Bhatty R.S., 1987. Relationship between acid extract viscosity and total soluble and insoluble $\beta$-glucan contents of hulled and hulless barley. Can. J. Plant Sci. 67, 997-1008

Bhatty R.S., MacGregor A.W. and Rossnagel B.G., 1991. Total and acid-soluble -glucan content of hulless barley and its relationship to acid-extract viscosity. Cereal Chem. 68, 221-227

Eggum B.O., 1973. A study of certain factors influencing protein utilization in rats and pigs. Beretn. Report, 406, National Institute of Animal Science, Copenhagen, pp. 173

Eggum B.O., Beams R.M., 1983. The nutritive value of seed proteins. In: W. Gottschalk, H.P., Muller (Editors). Seed proteins. Nijhorf/Junk, The Hague, pp. 499-531 
Graham H., Hesselman E., Jonsson E., Åman P., 1986. Influence of $\beta$-glucanase supplementation on digestion of a barley-based diet in the pig gastrointestinal tract. Nutr. Rep. Inter. 34, 1089-1096

Horaczyński H., Buraczewski S., Mucha S., 1981. Nutritive valuc of barlcy protein. 1. Estimation of the nutritive value of protein of different varictics of summer baley on growing rats (in Polish). Rocz. Nauk rol., Ser. B, 101, 7-21

Mason V.C., Bech-Andersen S., Rudemo M., 1980. Hydrolysate preparation for aminoacid determination in feed constituents. Z. Tierphysiol. Ticrernähr. Futtermittelk. 43, 35-48

McGinnis G.D., 1982. Preparation of aldononitrile acelates using $\mathrm{N}$-methylimidazole as catalyst and solvent. Carbohyd. Res. 108, 284-292

Polkowski W., 1996. Personal information. ZDHAR Radzików, Poland

Sauer W., Ozimck L., 1986. Digestibility of amino acids in swine: results and their practical applications. A review. Livest. Prod. Sci. 15, 367-388

Schneeman B.O., Richter B.D., Jacob L.R., 1982. Response to dietary wheat bran in the exocrine pancreas and intestine of rats. J. Nutr. 112, 283-286

Smith D.B., Morgan A.G., Aastrup S., 1980. Variation in the biochemical composition of acid extracts from barleys of contrasting malting quality. J. Inst. Brew. 86, 277-283

\section{STRESZCZENIE}

\section{Sklad i wartość żywieniowa jęczmienia nagiego}

Zastosowano chemiczne i biologiczne metody celem określenia wartości żywicniowej trzech rodów jęczmienia nagiego w porównaniu $z$ obecnic uprawianą odmianą tradycyjną Lot. Kryteriami jakościowej oceny były: zawartość białka i jego skład aminokwasowy, zawartość i skład włókna pokarmowego (DF) oraz niecelulozowych polisacharydów (NCP), a także strawność białka (TD) i suchej masy (DMD), wartośc biologiczna (BV) i wykorzystanie biakka (NPL) oznaczone na szczurach. Rody jęczmienia nagiego zawierały więcej białka (13,4 vs. 15,3\%), lecz koncentracja lizyny w białku byla niższa ( 3,14 vs. 2,86$)$ niż w odmianie Lot. Brak łuski wpłynął na niżsłą zawartość nierozpuszczalnego włókna pokarmowego (IDF) i nierozpuszczalnych arabinoksylanów (odpowiednio o 44 i $41 \%$ ) oraz na wyższą zawartość rozpuszczalnego $\beta$-gluknanu (o $58 \%$ ). Na szczurach TD i DMD były dodatnio skorelowane z zawartością białka $(r=0,80$ i 0,78 , odpowiednio $)$ i ujemnie z IDF ( $\mathrm{r}=-0,75 \mathrm{i}-0,95$, odpowicdnio). Stwierdzono, że badane ziarno jęczmiena nagiego miało istotnic wyższą wartość pokarmową nì odmiana tradycyjna Lot z łuską. Wykorzystanie białka jęczmienia nagiego jest jednak jeszcze bardziej, niż konwencjonalnego, ograniczone niskim poziomem lizyny. 